\title{
$M$ 系列を用いた空気圧疲労試験機周波数特性の解析*
}

\section{劉 小 平**, 荒 木 獻 次*** \\ Frequeny Characterictics Analysis of a Pneumatic Fatigue tester with M-sequence Input}

\author{
Xiao-ping LIU, Kenji ARAKI
}

Low-damping and low-robustness characteristics of pneumatic servo systems are sometimes troublesome for the ordinary control systems, but if the pneumatic system is applied to a fatigue tester, and worked near the resonant frequency, then a quick and energy-saving fatigue test can be implemented. For this purpose, it is necessary to know the frequency characteristics of the fatigue tester with a test object. However, because of its strong nonlinearity, the conventional sinusoidal input analysis method is too time-consuming.

This paper proposes a new method, which adopts the advantage of both $\mathrm{M}$-sequence and sinusoidal signals. With this method, a quick and precise frequency characteristics analysis can be achieved. First, the time response of the system to $\mathrm{M}$-sequence input is calculated, then through the FFT analysis of both the input and output signals, the system frequency characteristics can be obtained. Then, coordinated by the sinusoidal input calculation at some special frequencies, the optimal test frequency can be determined. At the frequency for the same amplitude under the same load, the air consumption of the tester for one cycle would be kept to a minimum. Comparisons have been made between the experiment and simulation for six pieces of test object samples. The results show that the optimal frequencies predicted by the simulation agree well with experimental ones. Finally, the load influence on the optimal test frequency is illustrated.

In the paper, comparisons have been also made between the frequency characteristics obtained with sinusoidal and $\mathrm{M}$-sequence inputs for different signal amplitudes. Also the influence of Coulomb friction on the characteristics is discussed.

Keywords: M-sequence, Pneumatics, Fatigue tester, Simulation, Frequency characteristics

\section{1.はしがき}

空気圧系の特徵の一つとしてダンピングが極めて低 いことが挙げられる.この特徴を利用して疲労試験機 の励振力発生機構に電気空気圧サーボ系を応用すれば, 試験を行なう過程での消費エネルギーを節約すること ができる1).そのためには, あらかじめ共振, 反共振お よび疲労試験を行なうための最適な周波数など, 試験 対象のついた状態での空気圧サーボ系の周波数特性の 解析が必要である.しかし, 空気圧系は非線形性が強

\footnotetext{
*平成 4 年 8 月 14 日 原稿受付

**埼玉大学大学院

****埼玉大学工学部

(所在地 $=338$ 浦和市下大久保255 埼玉大学工学

部機械工学科計測研究室)
}

いので，一般に線形近似が難しい. 従来の方法として は，そのような非線形系に対して記述関数法を適用し ていたが，正弦波入力により一周波数ずつ計算する必 要があるので, 周波数特性の計算に時間がかかりすぎ るという問題があった。

そこで著者等は, 系の周波数特性の同定実験 ${ }^{2} に お ~$ いて入力信号としてょく用いられるM系列3ををミュ レーションの分野に導入して, 短時間で空気圧系の周 波数特性を求める方法 ${ }^{4) 5}$ を提唱した。本論文では，そ の方法を空気圧疲労試験機 ${ }^{6}$ に適用し，また，正弦波入 力による周波数特性も求め, 両者の比較・検討を行っ た. 最後に, 得られた周波数特性より, 疲労試験を行 なう最適な周波数の決定法およびその最適周波数と試 験対象の関係についても述べる. 


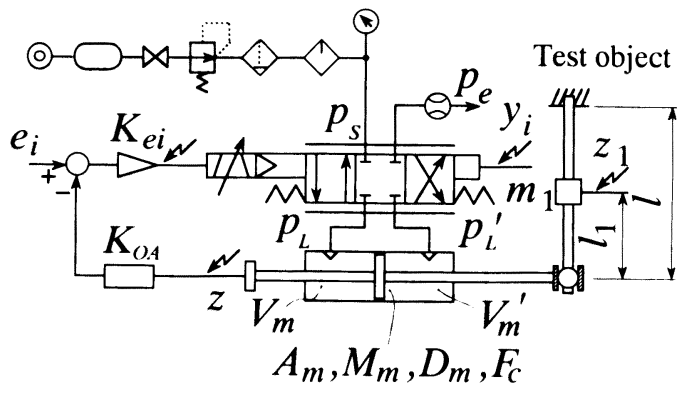

Fig. 1 Experimental system of a pneumatic fatigue tester

\section{2. 実験装粗とその数学モデル}

Fig.1に試験対象を含む疲労試験機の実験装置全体 （以下系と略称）の概略を示す．試験機の励振力発生 機構はサーボ弁とシリンダからなる電気空気圧サーボ 系である．試験対象を含む負荷は，一般的に質量・ば ね系として近似することができる，本実験では質量を その中間に固定した鋼の丸棒を試験対象として使用し た。電気空気圷サーボ系への人力信号, すなわち M系 列もしくは涯弦波はコンピュータで発生する.ピスト ン位置 $z$ と負荷質量 $\left(m_{1}\right)$ の位置 $z_{1}$ は容量型マイクロ メータで測定した。

Fig. 2にFig. 1负荷のついた案内弁・シリンダ部分 のモデルを示す.

解析に使用する記号をFig. 2ならびに以下に示す. サーボ弁に関する記号：

$b_{p}$ は制御オリフィスのポート幅 $8[\mathrm{~mm}], e_{i}$ はサーボ 弁への入力信号 $[\mathrm{V}], p_{e}$ は大気圧 $0.1013[\mathrm{MPa}], p_{s}$ は 供給压力 $0.49[\mathrm{MPa}] ， T_{s}$ はサーボ弁の時定数 $0.015[\mathrm{~s}], y_{i}$ はスプール変位 $[\mathrm{cm}], w_{1}, w_{2}, w_{1}{ }^{\prime}, w_{2}{ }^{\prime}$ は制御オリフィスの質量流量 $[\mathrm{kg} / \mathrm{s}], \Delta_{1}, \Delta_{2}, \Delta_{1}^{\prime}$, $\Delta_{2}^{\prime}$ 'は負重合量で各々 $16.2[\mu \mathrm{m}], 19.8[\mu \mathrm{m}]$, $16.2[\mu \mathrm{m}], 19.8[\mu \mathrm{m}], \rho_{e}$ は大気密度 $1.2\left[\mathrm{~kg} / \mathrm{m}^{3}\right]$ シリンダに関する記号：

$A_{m}$ は有効断面積 $10.5 \times 10^{-4}\left[\mathrm{~m}^{2}\right], D_{m}$ は粘性抵抗係 数 $68.6[\mathrm{Ns} / \mathrm{m}], F_{c}$ はクーロン摩擦力 $6.4[\mathrm{~N}], L$ はス トローク $15.5[\mathrm{~cm}], M_{m}$ は可動部質量 $2.5[\mathrm{~kg}], p_{L}$, $p_{L}^{\prime}$ はそれぞれ左有両負荷ポート压 $[\mathrm{MPa}] ， V_{m}$ は片 側容積 $82.5 \times 10^{-6}\left[\mathrm{~m}^{3}\right], w, w^{\prime}$ はシリンダへの質量流 量 $[\mathrm{kg} / \mathrm{s}], z$ はピストン変位 $[\mathrm{cm}]$, 負荷（試験対象を含む）に関する記号：

$D_{m 1}$ は粘性抵抗係数 $5[\mathrm{Ns} / \mathrm{m}]$, $f_{a n}=\frac{1}{2 \pi} \sqrt{\frac{k_{1}+k_{2}}{m_{1}}}$ は共振周波数 $[\mathrm{Hz}], F_{c 1}$ はクー

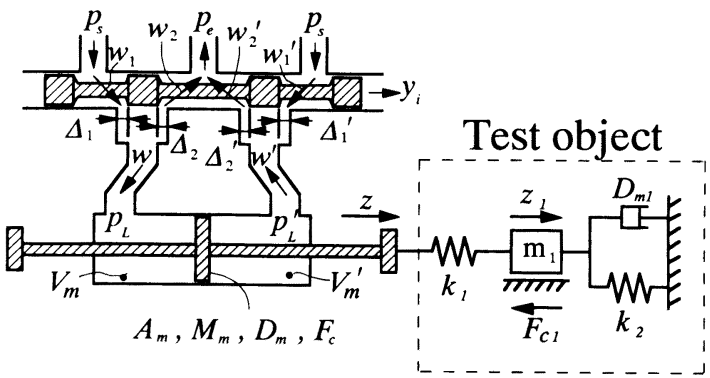

Fig. 2 Physical model of the pneumatic valve controlled cylinder with a test object

ロン摩擦力 $0.1[\mathrm{~N}], k_{i}(i=1,2)$ はばね定数 $[\mathrm{Ns} /$ $\mathrm{m}], m_{1}$ は質量 $[\mathrm{kg}], z_{1}$ は変位 $[\mathrm{cm}]$,

系に関する記号：

$f_{n}$ は電気空気圧サーボ系の無負荷共振周波数 $12[\mathrm{~Hz}], f_{n p}$ は $f_{a n}$ に強く依存した共振周波数, $f_{n t}$ は $f_{n}$ に強く依存した共振周波数 $[\mathrm{Hz}], f_{o p}$ は疲労試験機の 最適試験周波数 $[\mathrm{Hz}], K_{e i}$ は増幅器とサーボ弁のゲ イン定数 $0.037[\mathrm{~cm} / \mathrm{V}], K_{O A}$ はフィードバックゲイ ン $0.3[\mathrm{~V} / \mathrm{cm}]$,

実験結果とシミュレーションの結果に関する記号：

$G_{z}(f), G_{z s}(f), G_{z 1}(f), G_{z 1 s}(f)$ はそれぞれ $G_{z}$ $(j \omega), G_{z s}(j \omega), G_{z 1}(j \omega), G_{z 1 s}(j \omega)$ のゲイン,

$G_{z}(j \omega)=\frac{Z(j \omega)}{E(j \omega)}, G_{z s}(j \omega)=\frac{Z_{s}(j \omega)}{E(j \omega)}$ は各々入力信号 $e_{i}$ からピストン位置 $z$ までの周波数特性の実験結果 とシミュレーション結果, $G_{z 1}(j \omega)=\frac{Z_{1}(j \omega)}{E(j \omega)}$,

$G_{z 1 s}(j \omega)=\frac{Z_{1 s}(j \omega)}{E(j \omega)}$ は各々入力信号 $e_{i}$ から負荷位置 $z_{1}$ までの周波数特性の実験結果とシミュレーション 結果

系についての基礎式

サーボ弁並びにシリンダの質量流量》は，

$$
\begin{aligned}
& w_{1}=F f\left(\Delta_{1}+y_{i}\right) h_{1}, \quad w_{2}=F f\left(\Delta_{2}-y_{i}\right) h_{2}, \\
& w_{1}{ }^{\prime}=F f\left(\Delta_{1}{ }^{\prime}-y_{i}\right) h_{1}{ }^{\prime}, w_{2}{ }^{\prime}=F f\left(\Delta_{2}{ }^{\prime}+y_{i}\right) h_{2}{ }^{\prime} \text {, }
\end{aligned}
$$

ここて

$$
\begin{aligned}
& F=c_{d} b_{p} \sqrt{\frac{2 x p_{e}}{(x-1) p_{e}}} p_{s} H, H=\sqrt{\frac{x-1}{x+1}\left(\frac{2}{x+1}\right) \frac{2}{x-1}} \\
& f(x)= \begin{cases}x & (x \geq 0) \\
0 & (x \leq 0)\end{cases}
\end{aligned}
$$




$$
\begin{aligned}
& h_{1}=h_{1}\left(p_{L}\right)=\left\{\begin{array}{cc}
\frac{\sqrt{\left(\frac{p_{L}}{p_{s}}\right)^{\frac{2}{x}}-\left(\frac{p_{L}}{p_{s}}\right)^{\frac{x+1}{x}}}}{H} & \left(1 \geq \frac{p_{L}}{p_{s}} \geq 0.5283\right) \\
1 & \left(0.5283 \geq \frac{p_{L}}{p_{s}} \geq \frac{p_{e}}{p_{s}}\right)
\end{array}\right. \\
& h_{2}=h_{L}\left(p_{L}\right)=\left\{\begin{array}{l}
\left(\frac{p_{L}}{p_{s}}\right)^{\frac{x+1}{x}} \frac{\sqrt{\left(\frac{p_{e}}{p_{L}}\right)^{\frac{2}{x}}-\left(\frac{p_{e}}{p_{L}}\right)^{\frac{x+1}{x}}}}{H} \\
\left(1 \geq \frac{p_{e}}{p_{L}} \geq 0.5283\right)
\end{array}\right. \\
& \left(\frac{p_{L}}{p_{s}}\right)^{\frac{x+1}{x}} \quad\left(0.5283 \geq \frac{p_{e}}{p_{L}} \geq \frac{p_{e}}{p_{s}}\right) \\
& h_{1}{ }^{\prime}=h_{1}\left(p_{L}{ }^{\prime}\right), \quad h_{2}{ }^{\prime}=h_{2}\left(p_{L}{ }^{\prime}\right)
\end{aligned}
$$

である.ピストンの運動方程式は,

$$
\begin{aligned}
A_{m}\left(p_{L}-p_{L}{ }^{\prime}\right)= & M_{m} \frac{d^{2} z}{d t^{2}}+D_{m} \frac{d z}{d t} \\
& +F_{c v} \operatorname{sgn}\left(\frac{d z}{d t}\right)+k_{1}\left(z-z_{1}\right)
\end{aligned}
$$

ここで

$$
F_{c v}=\left\{\begin{array}{cc}
F_{c} & \left(\left|\frac{d z}{d t}\right| \geq 0.005[\mathrm{~m} / \mathrm{s}]\right) \\
3 \cdot F_{c} & \left(\left|\frac{d z}{d t}\right|<0.005[\mathrm{~m} / \mathrm{s}]\right)
\end{array}\right.
$$

ここで

$$
V_{1}=V_{m}+A_{m} z, \quad V_{2}=V_{m}-A_{m} z
$$

である.負荷質量の運動方程式は，

$$
m_{1} \frac{d^{2} z_{1}}{d t^{2}}+D_{m 1} \frac{d z_{1}}{d t}+F_{c v 1} \operatorname{sgn}\left(\frac{d z_{1}}{d t}\right)=k_{1}\left(z-z_{1}\right)-k_{2} z_{1}
$$

ここで

$$
F_{c v 1}=\left\{\begin{array}{cc}
3 \cdot F_{c 1} & \left(\left|\frac{d z_{1}}{d t}\right|<0.005[\mathrm{~m} / \mathrm{s}]\right) \\
F_{c 1} & \left(\left|\frac{d z_{1} \mid}{d t}\right| \geq 0.005[\mathrm{~m} / \mathrm{s}]\right)
\end{array}\right.
$$

スプール変位は,

$$
T_{s} \frac{d y_{i}}{d t}+y_{i}=K_{e i}\left(e_{i}-K_{O A} z\right)
$$

で表わされる。

\section{3 . 疲労試験機の理論解析と実験結果}

疲労試験を行う場合，できるかぎり試験時間の短縮 と消費エネルギーの節約を図りたい，そのためには，

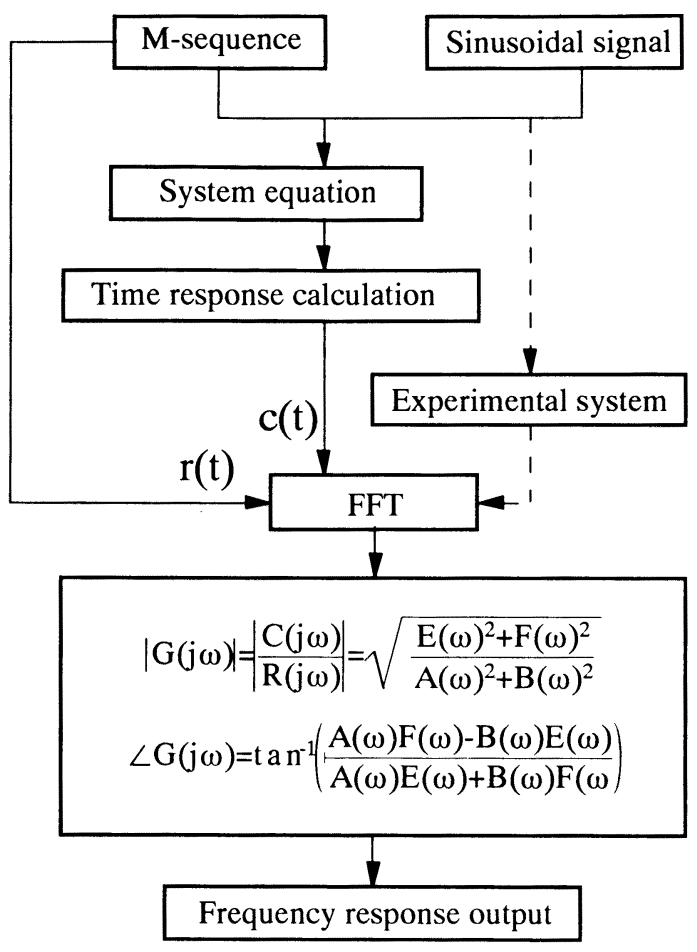

Fig. 3 Flow chart for obtaining the frequency response of a fatigue tester

系の周波数特性の把握が必要となる.

一般に周波数特性を求めるには正弦波入力を用いる ことが多い.しかし，シミュレーションにより系の周 波数特性を求める場合，正弦波入力を用いて，各周波 数に対してそれぞれ計算を行うのでは時間がかかりす ぎる.そこで短時間で周波数特性を求めるために，本 研究ではM系列入力を用いることにした。これによる 計算手順をFig. 3に示す．まずコンピュータでM系列 を発生し，これを入力信号とした系の応答を計算する。 その入力信号と応答をFFTにかけ，その結果より系の 周波数特性を求める.また，特定の周波数に対する周 波数応答を求める場合や，入力信号による計算結果の 相違を検討するために，M系列以外に正弦波入力を用 いた計算も行った。なおFig. 3中の点線は，実験によ り周波数特性を求める場合の手順を示している.

本研究では, ばね定数の違う三本の丸棒と重さの違 う二種類の質量を組み合せて, 合計六種類の負荷に対 する系の周波数特性などを検討した。それぞれの負荷 のパラメータの值と試験対象番号をTable 1に示す.

ここで $l, l_{1}, m_{1}, f_{a n}$ を実測し $f_{a n}=\frac{1}{2 \pi} \sqrt{\frac{k}{m_{1}}}$ より 
Table 1 Parameters of the test object samples

\begin{tabular}{|c|c|c|c|c|c|c|}
\hline Test object & $l[\mathrm{~mm}]$ & $l_{1}[\mathrm{~mm}]$ & $k_{1}[\mathrm{~N} / \mathrm{m}]$ & $k_{2}[N / m]$ & $m_{1}[\mathrm{~kg}]$ & $f_{a n}[\mathrm{~Hz}]$ \\
\hline 1 & 650 & 250 & 7010 & 14021 & 1.70 & 17.8 \\
\hline 2 & 650 & 250 & 7010 & 14021 & 2.03 & 16.2 \\
\hline 3 & 740 & 250 & 4300 & 8600 & 1.73 & 13.8 \\
\hline 4 & 740 & 330 & 4300 & 8600 & 2.06 & 12.6 \\
\hline 5 & 840 & 360 & 2820 & 5640 & 1.82 & 11.0 \\
\hline 6 & 840 & 360 & 2820 & 5640 & 2.12 & 10.0 \\
\hline
\end{tabular}

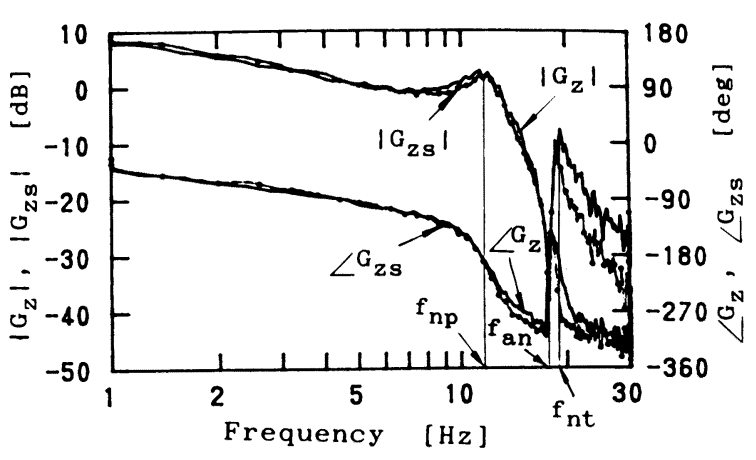

(a) $G_{z}(j \omega)$ and $G_{z s}(j \omega)$

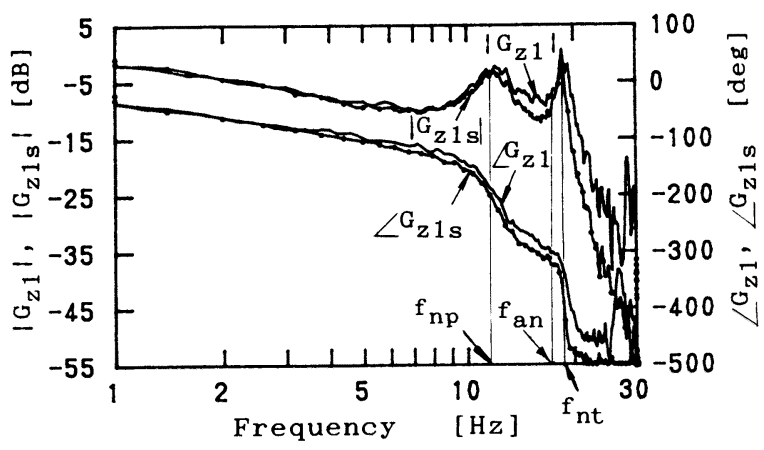

(b) $G_{z 1}(j \omega)$ and $G_{z 1 s}(j \omega)$

Fig. 4 Comparison between the simulation and the experimental results obtained with $\mathrm{M}$-sequence (Test object 1)

$k=k_{1}+k_{2}$ を算出し, $k_{1}$ と $k_{2}$ の振り分けは, $k_{1}=\beta k, k_{2}=$ $(1-\beta) k$ として周波数特性の実測值とシミュレー ション結果がなるべくあうような $\beta$ を採用した。

\section{1 实験結果とシミュレーション結果の比效}

Fig. 4 は負荷 $l=650[\mathrm{~mm}], m_{1}=1.73[\mathrm{~kg}]$ (試験対象 番号 1 ) に対して振幅 $\mid e d=2.0[\mathrm{~V}]$ の M系列入力の場 合の実験結果とシミュレーション結果の比較である。

Fig. 4(a) は入力信号 $e_{i}$ からピストン位置 $z$ までの周波 数特性であり, 実線は実験結果 $G_{z}(j \omega)$, 黒丸付きの実 線はシミュレーション結果 $G_{z s}(j \omega)$ である。両者は第 二共振点 $f_{n}$ 以上では多少ずれるが，それ以外ではかな りょく一致している.Fig. 4(b)は $e_{i}$ から $z_{1}$ までの周波数 特性 $G_{z 1}(j \omega)$ である. 高い周波数において, 両者の差も 大きくなっている，高周波における誤差は，実際の負 荷は分布定数系であるのに計算モデルは集中定数系で 近似したことによるものと考えられる。したがって高 い周波数での問題を検討する場合には, 分布定数系を 分割して，それぞれを集中定数系に近似するなどのモ デル改良が必要と思われる。

各試験対象の場合の実験結果とシミュレーション結
果の $0.2[\mathrm{~Hz}]$ から $20[\mathrm{~Hz}]$ までの間の差の平均を Table 2に示した. ここで

$$
\begin{aligned}
& E r r_{z}=\sqrt{\Sigma\left\{\left|G_{z}(j \omega)\right|-\left|G_{z s}(j \omega)\right|\right\}^{2} / N} \\
& E r r_{z 1}=\sqrt{\Sigma\left\{\left|G_{z 1}(j \omega)\right|-\left|G_{z 1}(j \omega)\right|\right\}^{2} / N}
\end{aligned}
$$

である.

\section{2 正弦波入カとM系列入力の場合の比較}

Fig. 5(a)，(b)は入力振幅 $\left|e_{e}\right|=0.7,1.0,2.0[\mathrm{~V}]$ (試 験対象番号 2 ) の場合の正弦波入力と $\mathrm{M}$ 系列入力の比 較実験結果である。Fig.6(a)，(b)はそれらに対応した シミュレーション結果である. 図によると, 共振点は 入力信号の振幅の隇少につれてゲインが下がっている. これはクーロン摩擦の影響と考えられる. 式(3)による ピストンの瞬時の摩擦抵抗 $F_{d}$ は

$$
F_{d}=D_{m e}\left(\frac{d z}{d t}\right)=D_{m}\left(\frac{d z}{d t}\right)+F_{c v} \operatorname{sgn}\left(\frac{d z}{d t}\right)
$$

ここで $D_{m e}$ は等価ダンピングで 
Table 2 Errors between the experimental and the simulation results for different test objects in the frequency range from $0.2[\mathrm{~Hz}]$ to $20[\mathrm{~Hz}]$

\begin{tabular}{|c|c|c|c|c|c|c|}
\hline & 1 & 2 & 3 & 4 & 5 & 6 \\
\hline$E r r_{z}[\mathrm{~dB}]$ & 1.21 & 1.25 & 1.50 & 1.51 & 1.75 & 1.82 \\
\hline$E r r_{z 1}[\mathrm{~dB}]$ & 1.80 & 2.21 & 2.10 & 2.40 & 2.50 & 2.01 \\
\hline
\end{tabular}

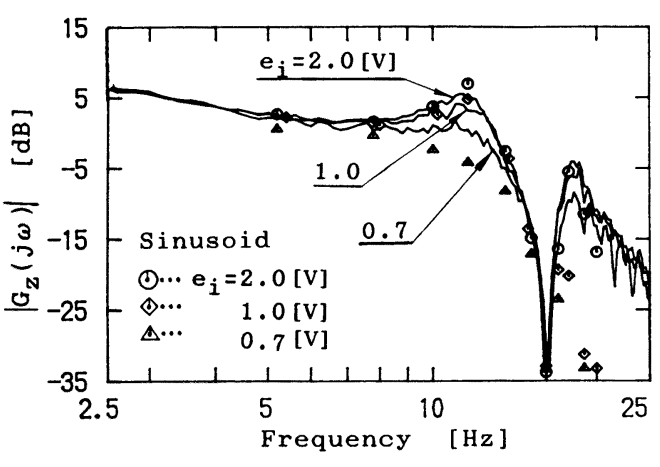

(a) $G_{z}(j \omega)$

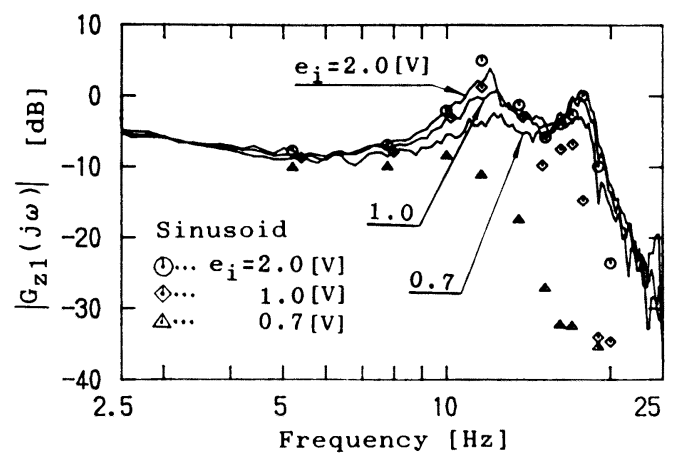

(b) $G_{z 1}(j \omega)$

Fig. 5 Comparison of frequency characteristics obtained from experiment with $\mathrm{M}$-sequence and with sinusoid for different signal amplitudes (Test object 2)

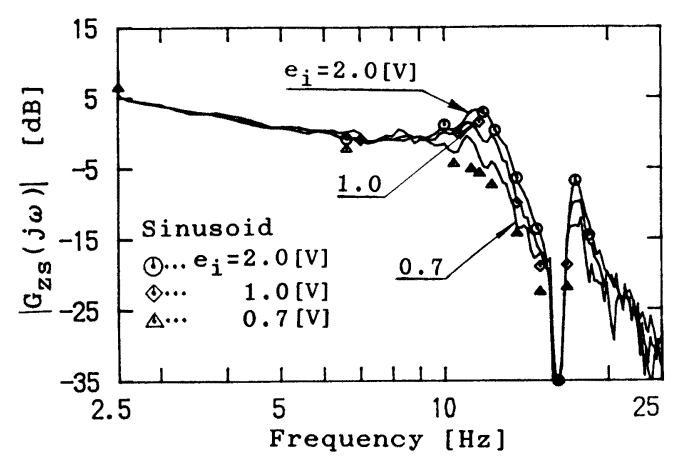

(a) $G_{z S}(j \omega)$

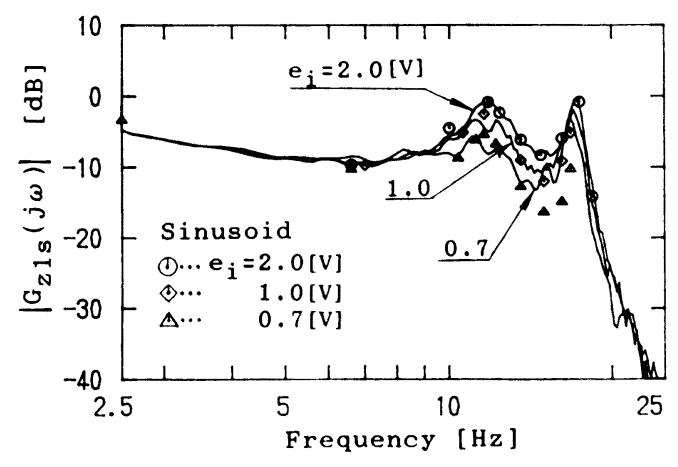

(b) $G_{z 1 s}(j \omega)$

Fig. 6 Comparison of frequency characteristics obtained from simulation with M-sequence and with sinusoid for different signal amplitudes (Test object 2)

$$
D_{m e}=\frac{D_{m}\left(\frac{d z}{d t}\right)+F_{c v} \operatorname{sgn}\left(\frac{d z}{d t}\right)}{\left(\frac{d z}{d t}\right)}=D_{m}+\frac{F_{c v}}{\left|\frac{d z}{d t}\right|}(9)
$$

と表せる.式(9)によるとピストンの速度が低いほど $D_{m e}$ は大きくなる．そのため同一種類の入力信号で考 えると,振幅が低いほど $D_{m e}$ が大きくなる.また同じ振 幅の正弦波とM系列を比較した場合には, 飽和などが 起こらない限りでは, 入力信号の振幅が十分大きい場 合 (例えば $\left|e_{2}\right|=2[\mathrm{~V}]$ ) 両者は良くあうが, 入力振幅が
小さくなると正弦波入力で求めたゲインの方がM系列 のそれより小さくなる.これは正弦波入力の場合に入 力振幅が小さいと, ピストンの速度も小さくなり, ピ ストンが動いたり停止したりすることもでてきて， クーロン摩擦が大幅に変化し, 動摩擦から静摩擦に, あるいはその逆に変わることもあるためと考えられる. M系列入力の場合には, 信号中にいろいろな周波数成 分を含むのでディザー効果があり絶えず動いていて停 止しないので, 正弦波入力の場合より摩㩯の変化の影 響が小さくなる。 


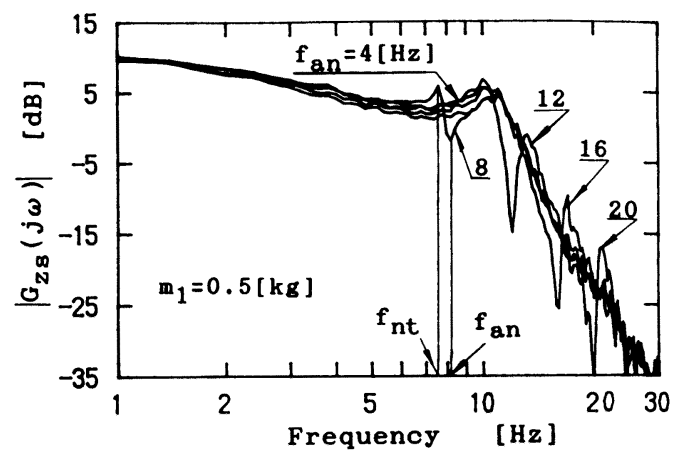

(a) $G_{z s}(j \omega)$

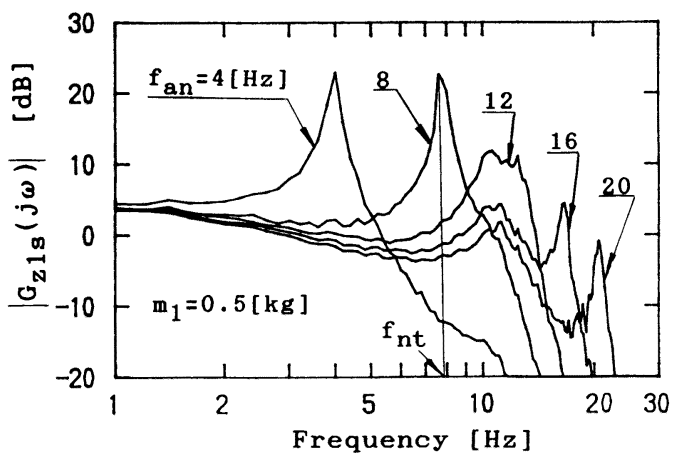

(b) $G_{z 1 s}(j \omega)$

Fig. 7 Influence of the test object resonance frequency $f_{a n}$ on the system frequency characteristics

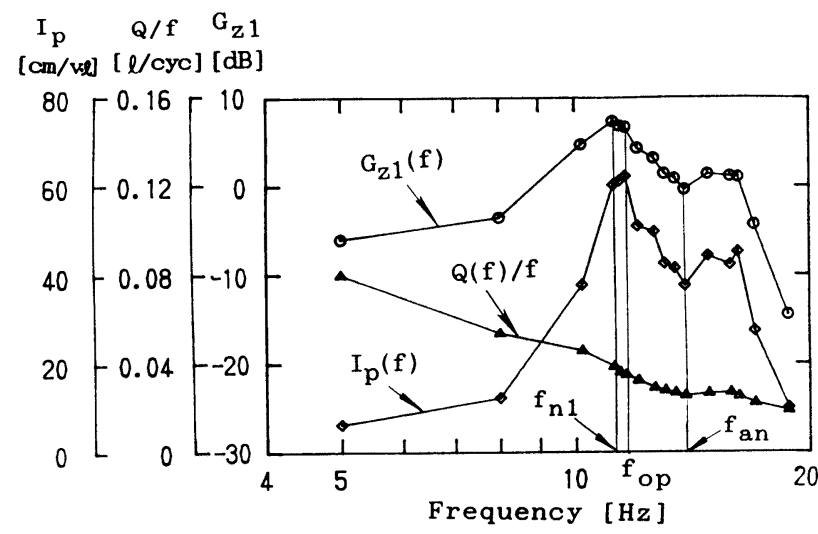

Fig. 8 Experimental determination of the optimal test frequency $f_{o p}$ (Test object 3)

\section{3 荷共振周波数 $f_{a n}$ が周波数特性に及ぼす影淎}

Fig. 7(a), (b)は, $m_{1}=0.5[\mathrm{~kg}]$ のとき, 負荷共振周波 数 $f_{a n}=4,8,12,16,20[\mathrm{~Hz}]$ の場合に計算した $G_{z s}$ $(j \omega)$ と $G_{z 1 s}(j \omega)$ である. 図によると, 系の周波数特性 は $f_{a n} \geq f_{n}=12[\mathrm{~Hz}]$ と $f_{a n}<f_{n}$ により著しく変わる. $f_{a n} \geq$ $f_{n}$ の場合は, $G_{z 1 s}(j \omega)$ の共振点は二つある. $f_{a n}<f_{n}$ の場 合は共振点は一つになり, その共振点ゲインは $f_{a n}$ が $f_{n}$ よりわずかに小さくなる間に急激に増大する。

\section{4. 消貫エネルギーの節約}

\section{1 最這試験周波数の決定}

定振幅疲労試験においては, 試験開始時からの振動 の総和が被試験物の寿命となる。このため負荷の振幅 が同じ場合，1サイクルあたりの系の空気消費量を少 なくすることにより消費エネルギーを節約することが できる.すなわち, 次式の性能指数 $I_{p}(f)$ の值が大きい ほど消費エネルギーが少なくなる。

$$
I_{p}(f)=G_{z 1}(f) /\{Q(f) / f\}
$$

ここでQ $(f)$ は正弦波入力の一周期に対しての系の平 均空気消費量で, 瞬間流量 $q(f)$ により

$$
Q(f)=\left\{\int_{0}^{1 / f} q(t) d t\right\} \times f /|E(j \omega)|
$$

のように表される。また， $I_{p}(f)$ の一番大きい周波数を 最適試験周波数 $f_{o p}$ と呼ぶ.

$$
f_{o p}=I_{p}^{-1}\left[\max \left\{I_{p}(f)\right\}\right]
$$

Fig. 8 は正弦波入力の場合, $l=770[\mathrm{~mm}], m_{1}=$ $1.73[\mathrm{~kg}]$ (試験対象番号 3 ) $の G_{z 1}(f), Q(f) / f, I_{p}(f)$ の実験結果である. Fig. 8に示すように $I_{p}(f)$ は， $f_{o p}$ に おいてほかの周波数に比べて著しく高くなっているの がわかる．その周波数において疲労試験を行えば消費 エネルギーを大幅に節約することができる．実験に よって $f_{o p}$ を探すことはそれほど難しいことではない が，計算で探すとなると大変時間がかかる．そのため 短時間で $f_{o p}$ を探す方法が必要であるが, M系列入力は このためにも極めて適している.

1) $f_{a n} \geq f_{n}$ の場合 
Table 3 Comparison of the optimal test frequencies $f_{o p}$ predicted by simulation with those found through experiments for different test objects

\begin{tabular}{|l|c|c|c|c|c|c|}
\hline & 1 & 2 & 3 & 4 & 5 & 6 \\
\hline Exp. $f_{o p}$ & 12.8 & 12.6 & 11.2 & 10.6 & 10.0 & 9.2 \\
\hline Sim. $f_{o p}$ & 12.8 & 12.4 & 11.4 & 10.8 & 10.0 & 9.2 \\
\hline
\end{tabular}

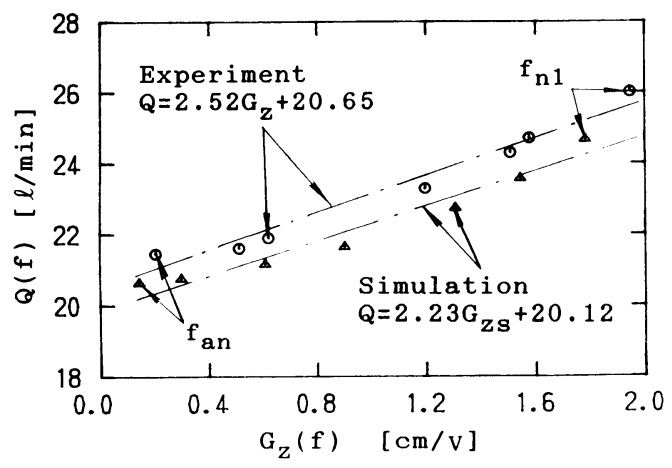

Fig. 9 Linear correlation between the flow $Q(f)$ and the piston gain $G_{z}(f)$ in the frequency range $\left[f_{n t}, f_{a n}\right]$ (Test object 3 )

Fig. 8 による $Q(f) / f$ は減少関数であり, $G_{z 1 s}(f)$ は 二つの極大值を持つ. 式(10)による $f_{o p}$ は区間 $\left[f_{n p}, f_{a n}\right]$ と $\left[f_{n t}, \infty\right]$ に存在しうる. しかし反共振周波数 $f_{a n}$ (負荷 の共振周波数と同一) 以上の周波数においては摩擦の ためピストンが動きにくい, あるいは動かない場合が あるので, 実際には $f_{o p}$ は区間 $\left[f_{n p}, f_{a n}\right] に$ 選定するのが 良い。

一般に, 系の空気消費量 $Q(f)$ はピストン変位と関係

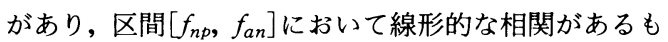
のと思われる. 実際に計測とシミュレーションした結 果は, Fig. 9のとおりで, $G_{z s}(f)$ とQ $(f)$ の間にほぼ線

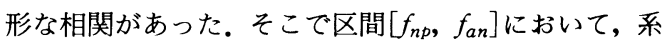
の空気消費量はピストンが動かない場合にサーボ弁だ

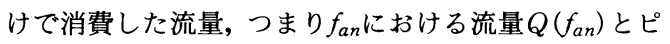
ストンが動くための流量 $\Delta Q(f)$ との重畳と考えられ, 次式がほほ成立する。

$$
Q(f)=Q\left(f_{a n}\right)+\Delta Q(f)
$$

ここで

$$
\Delta Q(f)=a G_{z s}(f)
$$

とおくと, 式(12)は次式となる.

$$
\begin{aligned}
& Q(f)=b+a G_{z s}(f) \\
& b=Q\left(f_{a n}\right)
\end{aligned}
$$

ここで $a, b$ は定数で, もし, $Q\left(f_{a n}\right)$ と区間 $\left[f_{n p}, f_{a n}\right]$ の うちの, $f_{n p}$ に少し寄った他の一周波数 $f_{1}$ の正弦波に対
する $Q\left(f_{1}\right)$ を計算すれば $\mathrm{a}$ が決められる $\left(Q\left(f_{n p}\right)\right.$ の計 算は一般に時間がかかる).

$$
a=\left\{Q\left(f_{1}\right)-Q\left(f_{a n}\right)\right\} / G_{z s}\left(f_{1}\right)
$$

式(14)を式(10)に代入すると

$$
I_{p}(f)=G_{z 1 s}(f) \times f /\left\{b+a G_{z s}(f)\right\}
$$

式(17)を式(11)に代入すると

$$
f_{o p}=I_{p}^{-1}\left\{\max \left[G_{z 1 s}(f) \times f /\left\{b+a\left(i_{z s}(f)\right\}\right]\right\}\right.
$$
ここで, $G_{z 1 s}(f)$ と( $i_{z s}(f)$ がM系列で求められるので, $f_{o p}$ は極めて短時間に計算できることになる。

2) $f_{a n}<f_{n}$ の場合

Fig. 70)示すように $f_{a n} \leq f_{n}=12[\mathrm{~Hz}]$ 0)場合に， $G_{z 1 s}$ $(f)$ は一つの極大值になり, $f_{o p}$ は $\left[f_{n t}, \infty\right]$ に存在しう る. また $f_{n t}$ の近傍では $G_{z 1 s}(f)$ の)゙インの変化は極めて 大きいため, 式(10)の流量 $Q(f)$ 0)変化は省略することが できる。そこで式(11)より

$$
\begin{aligned}
f_{o p} & =I_{p}{ }^{-1}\left[\max \left\{G_{z 1 s}(f) \times f / Q(f)\right\}\right] \\
& =I_{p}{ }^{-1}\left[\max \left\{G_{z 1 s}(f) \times f\right\}\right]
\end{aligned}
$$

しかし,この場合には $G_{z 1 s}(f)$ の共振点ゲインが大きい ため，場合によっては試験における $z$ の振幅を非常に 小さな值に制御する必要がある、クーロン摩擦F碑のた め, ピストンの動きが悪くなり試験ができなくなった りすることがある。すなわち,クーロン摩擦があるた め試験周波数に応じて試験可能なピストン振動振幅の 下限がある。

Table 3に, 正弦波入力の実験により探したExp・积， およびM系列入力で式(18)，(19)によりシミュレーション で求めた $\operatorname{Sim} ・ f_{o p}$ を示す.この表より, M系列と正弦波 で探した最適試験周波数 $f_{o p}$ がほほ同じであることが わかる.

\section{3 負荷が $f_{o p}$ と只 $\left(f_{o p}\right)$ に及はす影䈏}

本論文における $k_{1}, k_{2}, m_{1}$ は試験対象を含む負荷のば 权定数と負荷質量である。多くの場合, 疲労試験に先 立ち,これらのパラメー夕は実際の使用状況を配慮し 適当に選定（試験対象の設計）できる部分である。そ こで $k_{1}, k_{2}, m_{1}$ と $f_{o p}, I_{p}\left(f_{o p}\right)$ の)関係を検討する必要が ある. Fig. 10(a)は $\mathrm{m}_{1}=1.0,1.5,2.0[\mathrm{~kg}]$ の場合の $f_{a n}$

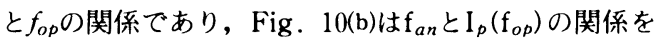
示す. Fig. 10(b)は $f_{a n} / f_{n}$ により三つの部分に分けて考 えることができる.まず $f_{a n} / f_{n} \geq 1.50$ 場合, $I_{p}\left(f_{o p}\right)$ はほ 


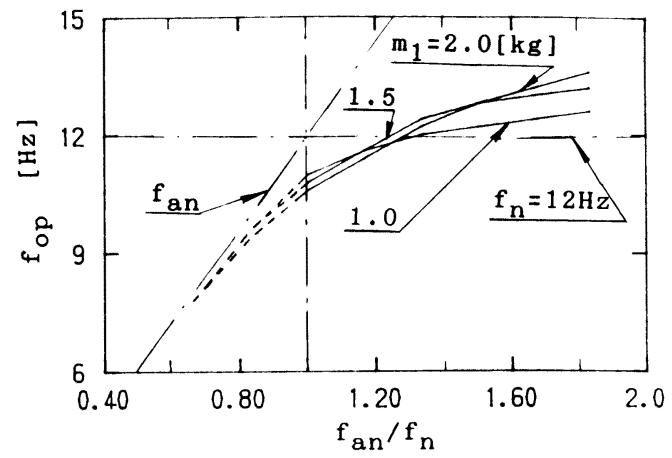

(a) Influence of the $f_{a n}$ on the optimal test frequency $f_{o p}$

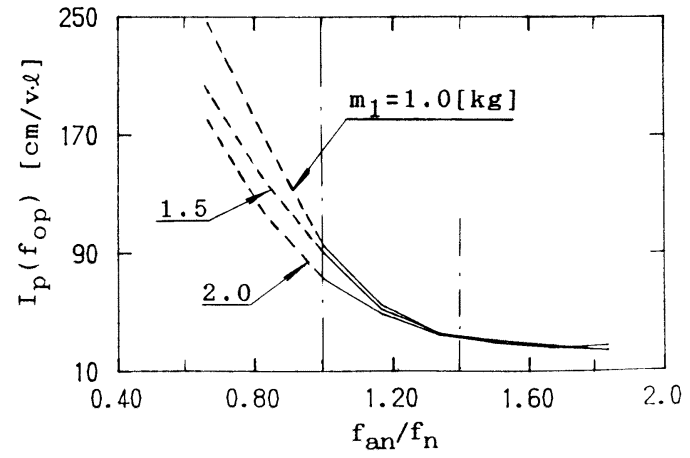

(b) Influence of the $f_{a n}$ on the $I_{p}\left(f_{o p}\right)$

Fig. 10 Influence of the test object resonance frequency $f_{a n}$ on the performance of the fatigue tester $\left(f_{n}\right.$ : resonance frequency of the tester without load)

ほ一定である. 次に $1 \leq f_{a n} / f_{n}<1.50$ 場合, $f_{a n}$ が小さ くなるにつれて, $I_{p}\left(f_{o p}\right)$ は大きくなる.したがって,こ の範囲では $f_{a n}$ が小さいほど消費エネルギーを節約す ることができる．これに対して $f_{a n} / f_{n}<1$ の場合には, 点線で示されている性能指数 $I_{s}\left(f_{o p}\right)$ は前述の二つの場 合に比べてかなり高いが，4.1章で説明したように， この $f_{a n} / f_{n}$ に対する最適試験周波数 $f_{o p}$ で試験が行なえ るのは, ピストンがうまく制御できる場合である.

\section{5.むすび}

M系列入力を用いて実験とシミュレーションにより 疲労試験機の周波数特性を求め, 以下の結論を得た。

1） M系列入力により, 周波数特性のシミュレーショ ンを, 極めて短時間で行えることを確認した。

2 ) $\mathrm{M}$ 系列入力と正弦波入力で求められた両周波数特 性は, 飽和が抢こらないかぎり, 入力振幅が大き いほどょく一致した。

また入力振幅が小さ過ぎると, クーロン摩擦の ために波労試験ができなくなる。

3）電気空気圧サーボ系を疲労試験機の励振力発生機 構に心用した場合, 適当な周波数で試験を行うと 消費エネルギーを節約することができることがわ かった。

4 ）疲労試験を行なうための最適試験周波数の決定法 を提唱した。

終わりに,本研究を行なうにあたり,ご意見を賜わつ た水野毅助教授, 湯室彰規助教授, また実験装置の作 成，論文の執筆に掯いてご協力をいただいた石野裕二 文部技官, 本学大学院生の大西輝幸氏, 学部生の菊地 裕二氏に深く感謝の意を表する。

\section{参 考 文 献}

1) K. Araki, S. Ichijou, Microcomputer Control of an Electro-Pneumatic Fatigue Tester, Proc. of ICFP'85, Hangzhou China, 1780/1799

2 ) 柏木潤, M系列再発見, 計測と制御, Vol. 20, No. $2,45 / 51$ (昭和 56 年 2 月）

3 ）森下䉷, 小畑秀文, 信号処理, 計測自動制御学会, $208 / 214$, 昭和 57 年

4) K. Araki, X.P. Liu, Y. Ishino, Frequency Response Simulation with $\mathrm{M}$-sequence and Its Application in Pneumatics, FLUCOME'91, $527 / 534$

5 ）荒木獻次，劉小平，M系列による空気圧系の周波 数特性の解析, 平成 3 年春季油空圧講演論文集, $101 / 104$

6) K. Araki, T. Yoshida, A Microcomputer Controlled Pneumatic Fatigue Tester, Proc. of ACl'83, 22-1/22-6

7 ) F.D. Ezekiel, J.L. Shearer, Pressure-Flow Characteristics of Pneumatic Valves, Trans. ASME, Vol. 79, 1577/1590 (1957)

8 ）荒木獻次，劉小平，M系列による空気圧疲労試験 機周波数特性の解析，第 9 回流体計測，第 6 回流 体制御合同シンポジウム講演論文集, $113 / 118$, 平 成 3 年

9 ）荒木獻次，劉小平，M系列による空気圧疲労試験 機周波数特性の理論・実験解析，平成 4 年春季油 空圧講演論文集, $81 / 84$ 